\author{
Ewa Kaptur \\ Uniwersytet im. Adama Mickiewicza w Poznaniu
}

\title{
Stylizacja języka bohaterek powieści Joanny Chmielewskiej na polszczyznę potoczną
}

Powieści Joanny Chmielewskiej mieszczą się w nurcie twórczości przeznaczonej głównie dla masowego odbiorcy szukającego rozrywki czy wartkiej akcji. Jest to literatura mocno osadzona we współczesnych realiach, bliska czytelnikowi przez tematykę i język, specyficzny typ humoru, parodystyczne ukierunkowanie fabuły itd. ${ }^{1}$. Pod względem gatunku utwory te należą przeważnie do powieści kryminalnych o zabarwieniu parodystyczno-humorystycznym².

Zaletami pisarstwa Chmielewskiej są: przenikanie się konwencji gatunkowych, dowcip językowy, łagodna ironia oraz stylizacja na potoczną odmianę

${ }^{1}$ Niejednokrotnie próbowano wyjaśnić fenomen twórczości Chmielewskiej. Badacze prozy pisarki zwracali uwagę na różne przyczyny tego zjawiska. Jak zauważa anonimowy autor artykułu zamieszczonego na oficjalnej stronie internetowej pisarki: „W latach istnienia Polski Ludowej nad kryminałami Chmielewskiej unosiła się pewna «egzotyka» wynikająca stąd, iż pisarka oprowadzała czytelnika po takich miejscach, jak kopenhaskie kasyno czy rezydencja brazylijskiego mafioso. Było w tych książkach wszystko to, co wysoko ceni sobie konsument literackiej rozrywki: porwania, przebieranki, gwałtowne zmiany akcji, zaskakujące puenty" (www.chmielewska.art.pl). Jednakże książki Chmielewskiej cieszą się wielkim powodzeniem także dziś. Dorota Pasich twierdzi, że w swoich książkach Chmielewska odwołuje się do bliskiej czytelnikowi rzeczywistości. „Akcja rozgrywa się zawsze lub przynajmniej częściowo w Polsce lub w środowisku polskim za granicą. Obowiązują polskie zwyczaje: wpadanie do znajomych, telefony w środku nocy, wyświadczanie dziwacznych przysług przyjaciołom, pożyczanie pieniędzy, książek i przedmiotów, palenie wielkiej ilości papierosów i wypijanie litrów kawy”. D. Pasich, Apetyt na Chmielewska, „Wiadomości Kulturalne” 1994, nr 30, s. 10.

${ }^{2}$ Rosjanie określają utwory Chmielewskiej trafnym mianem „kryminały ironiczne” - ironičeskij detektiv. 
polszczyzny w warstwie narracyjnej (pierwszoosobowa narracja) i w dialogach, której chciałabym się bliżej przyjrzeć w tym artykule 3 .

W swej analizie odwołam się do materiału pochodzącego z sześciu powieści, połączonych osobą narratorki, Joanny Chmielewskiej, utożsamianej onomastycznie i fabularnie z osobą pisarki. Są to następujące utwory: Wszyscy jesteśmy podejrzani (1966), Krokodyl z Kraju Karoliny (1969), Całe zdanie nieboszczyka (1972), Romans wszechczasów (1975), Studnie przodków (1979), Drugi watek (1993).

Wszystkie bohaterki analizowanych utworów Joanny Chmielewskiej posługują się polszczyzną stylizowaną na język potoczny ${ }^{4}$. Stylizacja to

celowe naśladowanie w wypowiedzi realizującej określony styl niektórych istotnych właściwości stylu innego, wyraziście rozpoznawalnego jako cudzy i zewnętrzny wobec wypowiedzi. Styl ten traktowany jest jako wzorzec stylizacyjny ${ }^{5}$.

W tym miejscu warto zaznaczyć, że stylizację na język potoczny omówię tylko na poziomie leksyki. Przy definiowaniu terminu „wyraz potoczny” (,kolokwializm”) korzystam z propozycji Ewy Masłowskiej:

za potoczne uznaję te wyrazy, które mają w odmianie literackiej swe neutralne odpowiedniki, charakteryzują się wyrazistą strukturą i nacechowaniem ekspresywnym, służą do wyrażania osobistej i emocjonalnej oceny realiów w kontekstach nieoficjalnych ${ }^{6}$.

Badane słownictwo kobiet będzie dotyczyło różnych sytuacji komunikacyjnych, np. rozmów ze współpracownikami, z rodziną, przyjaciółmi i znajo-

${ }^{3}$ Dokładnie o języku bohaterek powieści Joanny Chmielewskiej pisałam w innym artykule. Zob. E. Kaptur, Język bohaterek wybranych utworów Joanny Chmielewskiej, „Poznańskie Studia Polonistyczne. Seria Językoznawcza” X, 2003, s. 109-142.

${ }^{4}$ Językoznawcy do najbardziej charakterystycznych cech potocznej odmiany języka polskiego zaliczają: 1) prymarnie ustną (mówioną) formę wypowiedzi w opozycji do formy pisanej (postać pisana jako typ realizacji stylu potocznego języka jest znacznie rzadsza i na ogół wtórna); 2) powszechność zasięgu społecznego, spontaniczność, bezpośredniość, nieoficjalność, niespecjalistyczność; 3) swobodę, ekspresywność, familiarność, zwyczajowość; 4) mniejszą staranność wobec normy, emocjonalno-wartościujący charakter; 5) humorystyczną interpretację świata. Zob. J. Anusiewicz, Potoczność jako sposób doświadczania świata i jako postawa wobec świata, w: Potoczność w języku i kulturze, red. J. Anusiewicz, F. Nieckula, Wrocław 1992, Język a Kultura, t. 5, s. 11-12.

${ }^{5}$ M. Głowiński, T. Kostkiewiczowa, A. Okopień-Sławińska, J. Sławiński, Słownik terminów literackich, wyd. 3 poszerz. i popr., Wrocław 1998, s. 538.

${ }^{6}$ E. Masłowska, Myślenie potoczne w semantyce, w: Potoczność w języku i kulturze, red. J. Anusiewicz, F. Nieckula, Wrocław 1992, Język a Kultura, t. 5, s. 204. 
mymi. Ponieważ kobiety w taki sam sposób rozmawiają z przełożonym i z kochankiem, podział sytuacji komunikacyjnej na oficjalną i nieoficjalną wydaje się bezzasadny.

Już w pierwszym zetknięciu z bohaterkami powieści Chmielewskiej można stwierdzić, że wypowiadają się one w sposób bezpośredni i spontaniczny, często dosadny. Tak jest w następujących wypowiedziach:

Te jakieś tam swołocze za ścianą chcą, żebym im to powtórzyła, jeśli pamiętam... [...] A niechże mnie ręka boska broni teraz cokolwiek $\mathrm{z}$ tego $\mathrm{z}$ siebie wydusić! Jasne jest przecież, że natychmiast potem trzasną mnie w ciemię i po krzyku. Nie wiem, dlaczego trzasną, ale trzasną, jak amen w pacierzu! (CZN 23) ${ }^{7}$

- Co pan sobie wyobraża, że ja sobie wyobrażam, że pan nie wie, jak pan wygląda?!... [...]

- No dobrze - zgodził się. - Załóżmy, że ma pani rację, chociaż moim zdaniem bardzo pani przesadza. Ale nie rozumiem, w czym pani przeszkadza mój wygląd. - W czepianiu się pana - wyjaśniłam. - Nie mogę się czepiać człowieka, któremu nosem wychodzą czepiające się go kobiety. Dla mnie jest pan nieopisanie atrakcyjny w zupełnie innym sensie. (RW 116)

W języku bohaterek utworów Chmielewskiej dominuje ekspresywizm. Uczucia odgrywają niebagatelna rolę w życiu postaci kobiecych, co uwidacznia się także na poziomie języka ${ }^{8}$. Emocjonalność, jako jedna $\mathrm{z}$ cech języka potocznego, wpływa na sposób widzenia świata przez powieściowe bohaterki, na nazywanie elementów rzeczywistości. W ich uczuciowo nacechowanych wypowiedziach ważne miejsce zajmują wyrazy, zwroty i wyrażenia o charakterze potocznym.

Kolokwializmy leksykalne w utworach literackich pełnią funkcję świadomie wybranego środka stylistycznego. Wśród nich należy odnotować obecność pojedynczych leksemów należących do wszystkich części mowy, przy

${ }^{7}$ Fragmenty powieści cytuję według następujących wydań: Cate zdanie nieboszczyka, wyd. 4, Warszawa 1992 (dalej: CZN); Wszyscy jesteśmy podejrzani, Warszawa 2001 (dalej: WJP); Studnie przodków, Warszawa 2001 (dalej: SP); Krokodyl z Kraju Karoliny, wyd. 4, Warszawa 1993 (dalej: KzKK); Drugi watek, wyd. 2, Warszawa 1995 (dalej: DW); Romans wszechczasów, wyd. 2, Warszawa 1990 (dalej: RW). Za skrótem tytułu książki podaję numer strony.

${ }^{8}$ O językowym obrazie uczuć w prozie Chmielewskiej obszernie pisałam w dwóch artykułach. Zob. E. Kaptur, Nazwy uczuć w wybranych utworach Joanny Chmielewskiej. Emocje pozytywne, „Poznańskie Studia Polonistyczne. Seria Językoznawcza” XI, 2004, s. 97-109; eadem, Nazwy uczuć w wybranych utworach Joanny Chmielewskiej. Emocje negatywne, w: Studia nad polszczyznq wspótczesna i historycznq. Prace dedykowane Profesorowi Stanisławowi Babie w 65-lecie urodzin, red. J. Liberek, Poznań 2004, s. 147-157. 
czym trzeba podkreślić liczebną dominację czasowników, np.: ględzić 'mówić rozwlekle i bez sensu'9 (Ględził o majqtku po przodkach, jak byt u mnie w Kanadzie, SP 206), kręcić 'kłamać' (Coś kręcisz, skarbie drogi-powiedziałam stanowczo, KzKK 80), miotać się 'denerwować się, nie móc znaleźć sobie miejsca' (Czego wy się miotacie po nocy, jakby was pchty gryzły!, SP 96), nawalić 'zawieść kogoś, nie zrobić czegoś, o co ten ktoś prosił' (Nawalimy, jak Bóg na niebie, WJP 56), rabnać się 'pomylić się' (I nic nie będę wiedziała, dopóki mi nie udowodnisz, że się rąbęłam i niepotrzebnie się czepiam uczciwej, państwowej instytucji, KzKK 89), wydoić 'wyciagnąć coś od kogoś z jaką́s korzyścią' (Nic ze mnie nie wydoisz, bo jestem zniechęcona do egzystencji, CZN 132).

Mniej liczna jest grupa rzeczowników, np.: draka 'afera' (Ja bym się zgodziła dla samej draki, to on protestuje, bo głupi, RW 187), kłaki 'włosy' (Po dobrym szamponie odrażajace kłaki wygladały jeszcze jako tako przynajmniej przez dwa dni i czasem nawet mogłam sobie zrobić coś $w$ rodzaju uczesania, CZN 47), łachy 'rzeczy' (położyłam okropne, przegniłe łachy, które niegdyś stanowity moja wytworna odzież, CZN 183), pała 'głowa' (Przychodzi ci coś do tej tępej pały?, WJP 136), pudto 'samochód' (Nie wysiadziesz z tego pudła!!!, KzKK 107), rzęchy 'rzeczy' (nie podobałam się sobie, trójkątna twarz i koszmarne, workowate rzęchy na grzbiecie, DW 84), żarcie 'jedzenie' (Żarcie gotowe, światto świeci, proszę o dźwięk!, DW 231) oraz przymiotników i przysłówków, np.: cholernie, tu w znaczeniu 'bardzo' (To znaczy, że jesteśmy nad wyraz ściśle wmieszani w cholernie wielka międzynarodowa afere przemytu narkotyków, która nam wykończyła przyjaciółkę, KzKK 130), fajny 'dobry, ładny' (Ale wiecie, że to jest fajna historia, SP 84), idiotyczny, tu w znaczeniu 'dziwaczny' (Alicja obejrzała szminke, pomazała się nia po rece i zamyśliła się. - Bo ja wiem? Idiotyczny kolor..., WJP 236), kretyński 'pozbawiony sensu, dziwaczny, niedorzeczny’ (Kretyńska propaganda!, DW 228).

Bohaterki książek Chmielewskiej operują językiem pełnym frazeologizmów ${ }^{10}$. Mogą one występować w formie niezmienionej, np.: mieć coś gdzieś 'lekceważyć kogoś' (Mam gdzieś twoje hrabiostwo, SP 7), szlajać się 'włóczyć

9 Przy podawaniu znaczeń pojedynczych wyrazów i zwrotów frazeologicznych korzystałam z następujących słowników: S. Bąba, J. Liberek, Słownik frazeologiczny współczesnej polszczyzny, Warszawa 2001; Stownik języka polskiego, red. M. Szymczak, t. 1-3, Warszawa 1978-1981; Stownik języka polskiego, red. M. Bańko, t. 1-6, Warszawa 2007; Stownik wspótczesnego języka polskiego, red. B. Dunaj, t. 1-5, Kraków 2000-2004; S. Skorupka, Stownik frazeologiczny języka polskiego, t. 1-2, wyd. 9, Warszawa 1999; Uniwersalny stownik języka polskiego, red. S. Dubisz, t. 1-4, Warszawa 2003.

${ }^{10}$ Obszernie na ten temat pisała W. Michalak, Frazeologia i jej przeksztatcenia w twórczości Joanny Chmielewskiej, „Prace Literackie” XXIX, 1991, s. 175-191. Zob. także E. Kaptur, Język bohaterek..., s. 126-130. 
się’ (Na litość boska, gdzieś się szlajała?, KzKK 92), zamknqć komu gębe (Zamknijcie gęby i pozwólcie mu odpowiedzieć, SP 165), zaprawić kogoś czymś 'mocno uderzyć kogoś czymś' (Jak cię zaprawię tym kadtubem [upieczonego indyka - E.K.], to wylizany [przestępca - E.K.] nie będzie potrzebny...!, SP 81), lub być uzupełnione dodatkowymi członami: tu jest pogrzebany bardzo tadny pies, który mi się cholernie nie podoba? (WJP 152). W ostatnim przykładzie dokonano zamiany czasownika leżeć na być, zmieniono szyk wyrazów w związku: pies pogrzebany - pogrzebany pies, a także mocno rozbudowano cały zwrot przez jego wielowyrazowe dopełnienie: bardzo ładny [pies - E.K.], który mi się cholernie nie podoba.

Zdarza się, że w jednej wypowiedzi dochodzi do kontaminacji dwóch (lub więcej) różnych frazeologizmów, dzięki czemu wypowiedzi bohaterek zyskują efekt komiczny, np. w zdaniu moglibyście ruszyć wreszcie tymi głabami, co je macie na karku (SP 167) autorka wypowiedzi nawiązuje do trzech frazeologizmów: ruszyć głowa 'pomyśleć, wykoncypować coś, zdobyć się na inicjatywę, pomysł', mieć głowę na karku 'być sprytnym, przedsiębiorczym, zaradnym, umieć sobie radzić' i kapuściany głąb 'głupiec, tępak, niezdara'.

Często stosowanym zabiegiem stylistycznym jest także zastępowanie jednego członu związku frazeologicznego innym, np. we frazeologizmie włazić komuś w oczy 'nawinąc się, napatoczyć się' doszło do wymiany rzeczownika $o c z y$ na zęby, w wyniku czego powstała innowacyjna konstrukcja włazić komuś w zęby (Na głowę trzeba upaść, żeby mu tu w zęby włazić!!!, SP 111).

Stałe i zmodyfikowane związki frazeologiczne pojawiają się w języku wszystkich bohaterek, choć najczęściej występują w wypowiedziach Joanny, narratorki i głównej postaci wymienionych powieści. Służą one przede wszystkim uwypukleniu emocji, które towarzyszą bohaterkom (pełnią funkcję ekspresywna). Poza tym podkreślają autentyzm zaistniałych sytuacji, a także zwracają uwagę na ich komizm. Wanda Michalak zauważa ponadto, że

nagromadzenie związków frazeologicznych ma na celu stylizację warstwy językowej, ukształtowanie jej na wzór mowy potocznej, a jednocześnie spełnia ono funkcję humorystyczną i podnosi walor komizmu języka ${ }^{11}$.

Bohaterki powieści często używają wyrazów nacechowanych emocjonalnie, szczególnie w partiach dialogowych, kiedy zwracają się bezpośrednio do osób i płci męskiej, i płci żeńskiej, np.: Czekajcie, chamy niemyte (CZN 227), Do potomności to pan przejdzie jako naczelny głupek naszych czasów (WJP 56), Ten twój cały szef! [...] To łajdak!!! (CZN 168). Nasycenie wypowiedzi ko-

${ }^{11}$ W. Michalak, op.cit., s. 191. 
biet wyzwiskami, wulgaryzmami, zarówno typowymi: idiotka (KzKK 243), kretyn (WJP 90), pótgłówek (SP 184), świnia (CZN 290), jak też oryginalnymi: tysy knur (CZN 274), naczelny głupek naszych czasów (WJP 56), rozlazłe bubki z rozlazłymi nosami (SP 63), sprawia, że mowa bohaterek w znacznym stopniu upodabnia się do języka potocznego ${ }^{12}$. Dzieje się tak zazwyczaj w sytuacjach, gdy chcą one podkreślić oburzenie, zaskoczenie, złość.

W zwrotach adresatywnych bohaterki powieści Chmielewskiej wykorzystują także spieszczenia i zdrobnienia w funkcji wyrażeń obraźliwych, np.: kotku stodki (Kotku stodki, ja mam za sobq koszmar!, CZN 222), kwiatuszku (Sam będziesz, kwiatuszku, dbał o moje dtugie życie, CZN 141), skarbie (Stuchaj no, skarbie, RW 228). Wyrażenia te stanowią integralną cześć wypowiedzi bohaterek, informują o stylizacji nie tylko na język kolokwialny, ale również na język kobiet ${ }^{13}$. Trzeba pamiętać, że pojawiające się prymarnie lub sekundarnie obraźliwe zwroty adresatywne ${ }^{14}$ są zawsze uwarunkowane określoną sytuacją komunikacyjną. Zazwyczaj jest to sprzeczka czy kłótnia.

W wypowiedziach postaci kobiecych pojawiają się także bardzo liczne wykrzyknienia. W zdecydowanej większości są to ekspresywizmy zawierające imię boskie lub inny wyraz nawiązujący do imienia czy imion postaci świętych, np.: chwała bądź Panu na wysokościach! (Chwata badź Panu na wysokościach! Ty ślepa komendo, to nie byłam ja!, CZN 241), Jezus, Mario! (Jezus, Mario! - krzyknęła i zniknęła w umywalni, WJP 93), o, chwata Ci, Panie! (O, chwała $C i$, Panie, WJP 165), które pojawiają się również w zapewnieniach typu: jak Boga kocham! (Nic, jak Boga kocham!, SP 190), jak Bóg na niebie (Nawalimy, jak Bóg na niebie, WJP 56).

Nierzadkie są także wykrzyknienia zawierające różnego typu wulgaryzmy, np. cholera ciężka! (Stuchaj, strasznie cię przepraszam, zupetnie o tym zapomniałam! Okazuje się, że mam na jutro rano zrobić jeden obrazek. Cholera ciężka!, KzKK 17), po jakq cholerę! (Po jakq cholerę zadajesz głupie pytania?!, CZN 152).

W grupie wykrzyknień pojawiają się ekspresywizmy w rodzaju: po jakiego diabła? 'po co?' (Jak ci się zdaje, po jakiego diabła kazałam ci je ogladać?, KzKK 245), ki diabet 'kto to?' (Ki diabet?, SP 58).

12 Por. K. Handke, Wulgaryzmy w języku Polek XX wieku, w: Polszczyzna dawna i wspótczesna. Materiały z ogólnopolskich konferencji językoznawczych, red. C. Kosyl, Torun 1994, s. 53-55.

${ }^{13}$ Dokładnie pisała o tym K. Handke, Język a determinanty ptci, w: Płeć w języku i kulturze, red. J. Anusiewicz, K. Handke, Wrocław 1994, Język a Kultura, t. 9, s. 20; eadem, Styl kobiecy we współczesnej polszczyźnie kolokwialnej, „Studia z Filologii Polskiej i Słowiańskiej” XXVI, 1989, s. 23. Zob. także E. Kaptur, Język bohaterek..., s. 121-122.

${ }^{14} \mathrm{O}$ podziale wyrazów obraźliwych pisze m.in. K. Ożóg, $O$ wspótczesnych polskich wyrazach obraźliwych, „Język Polski” LXI, 1981, nr 3-5, s. 183. 
Inną charakterystyczną cechą języka bohaterek powieści Chmielewskiej jest używanie wyrazów onomatopeicznych typu: Aaaa...!! (RW 278), Iiii tam! (SP 154), Hrrhrrhrr...? (SP 80), Phi! (SP 154), Tfu (SP 77), szczególnie w sytuacjach, gdy brak im słów. Wyrazy te zastępują dłuższe zdania, dodatkowo podkreślają stosunek nadawcy do podmiotu lub przedmiotu będącego ośrodkiem zainteresowania mówiącego.

W analizowanych utworach pojawiają się także liczne przysłowia w postaci krótkich sentencji: Chłop w chatupie, to jak wrzód na dupie (DW 125) i zawołań: Cześć pracy, rodacy (KzKK 156), Niech mnie gęś kopnie (KzKK 245), U mnie kropka w kropke to samo (RW 101).

$\mathrm{Na}$ koniec warto odnotować, że wypowiedzi bohaterek powieści Chmielewskiej w dużym stopniu przesycone są humorem, kpiną, drwiną, ironią czy autoironią, co uwidacznia się przede wszystkim w partiach dialogowych, np.:

- No dobrze, wobec tego teraz myślmy rozsądnie...

- Potrafimy? - spytała Alicja z powątpiewaniem.

- Będziemy się starać. Zacznijmy od początku. Dlaczego Tadeusz wyszedł przed śmiercią z pokoju i poszedł do sali konferencyjnej?

- Bo po śmierci już by mu się to nie udało...

- Ja do ciebie mówię poważnie!

- Widocznie chciał zginąć w spokoju, a nie w tym hałasie, który oni tam robią. (WJP 150-151)

- Moglibyście ruszyć wreszcie tymi głąbami, co je macie na karku, i zdecydować się, gdzie trzeba szukać.

- A ty co, nie możesz ruszyć swoim głąbem? - obraziła się moja mamusia.

- Ja jestem najmłodsza i prababci nie pamiętam.

- Podfruwajka się znalazła! - prychnęła Lucyna. - Tyle samo wiesz, co i my! (SP 167)

- A teraz zawiadamiam cię, moje słodkie kochanie, że jak mi nie dasz jeść, to pluję na tę całą konwersację i odmawiam wszystkiego. Nic ze mnie nie wydoisz, bo jestem zniechęcona do egzystencji. Możesz mnie zabić zaraz i nie zawracaj mi głowy. (CZN 132)

Bohaterki omawianych powieści Chmielewskiej cechuje dystans do własnej osoby, co przejawia się choćby w wysuwaniu krytycznych uwag pod swoim adresem, zwłaszcza uwag dotyczących wyglądu zewnętrznego, np. narratorka po wyjściu z lochów stwierdza:

Nieboszczka po kilku ekshumacjach byłaby przy mnie okazem zdrowia i urody. $\mathrm{W}$ dodatku musiałaby to jeszcze być nieboszczka pochowana nie w trumnie, a lu- 
zem, tak, żeby ziemia cmentarna miała do niej swobodny dostęp, inaczej bowiem porównanie ze mną nie wchodziłoby w rachubę (CZN 182),

charakteru:

Nigdy jednakże nie miałam łagodnego, anielskiego charakteru i nigdy nie lubiłam robić za pożałowania godną ofiarę. Katusze moralne nigdy nie były dla mnie upragnionymi doznaniami. Nie wstrzymywałam się zbyt długo z wyjawieniem poglądów, rzuciłam się na niego z pazurami natychmiast po wyjściu na spacer, usiadłszy na obmurowaniu pierwszego kanału, jaki mi się napatoczył (RW 228)

czy umiejętności kulinarnych:

Jedyne co naprawdę umiem, to upiec drób, niech mi się nie marnują talenty. Zacznijcie od śledzika. (DW 187)

Trzeba podkreślić, że stylizacja języka bohaterek powieści Joanny Chmielewskiej na polszczyznę kolokwialną pojawia się w warstwie narracyjnej i w dialogach. Wszystkie bohaterki książek Chmielewskiej, postacie zarówno pierwszo-, jak i drugoplanowe, chętnie korzystają z zasobów polszczyzny potocznej. Operują barwnym językiem, pełnym ekspresywizmów. Nasycenie wypowiedzi licznymi kolokwializmami przybliża ich język do mowy potocznej. Autorka powieści wiernie odwzorowuje potoczną odmianę polszczyzny, wzbogacając ją dodatkowo różnego typu innowacjami językowymi. W wypowiedziach kobiet przeważa emocjonalny ton, co uwidacznia się w stosowaniu licznych wykrzyknień, wyrazów dźwiękonaśladowczych, zawołań czy wyrazów uważanych za wulgarne lub obraźliwe (także spieszczeń i zdrobnień występujących w funkcji wyrazów wartościowanych negatywnie).

Warto dodać, że słownictwo bohaterek powieści Chmielewskiej w dużym stopniu jest wartościowane pejoratywnie. Użycie wyrazów nacechowanych melioratywnie jest typowe tylko dla opisu stosunków damsko-męskich.

Ponadto język kobiet cechuje brak wyraźnego zróżnicowania słownictwa ze względu na sytuację komunikacyjną. Niezależnie od tego, czy widzimy bohaterki w sytuacji oficjalnej (np. rozmowa z przedstawicielami milicji, pracodawca), czy też nieoficjalnej (np. kontakty ze współpracownikami, przyjaciółmi), zachowują się one i mówią w podobny, sobie właściwy sposób. Brak widocznej granicy między dwoma różnymi sytuacjami komunikacyjnymi staje się więc istotnym wyznacznikiem stylu, którym posługują się powieściowe bohaterki.

Potoczność u Chmielewskiej przejawia się na poziomie języka, w znacznie mniejszym stopniu - w wyborze tematów. Brak tu typowej tematyki co- 
dziennej, związanej ze stereotypowo pojmowaną domeną działalności kobiet, innymi słowy, leksyki dotyczącej aktywności kobiet (dom, rodzina, dzieci) ${ }^{15}$.

Wypowiedzi powieściowych bohaterek nierzadko zabarwione są ironia, kpina, drwina, ale przede wszystkim humorem. Humorystyczny charakter języka potocznego uwarunkowany jest jednak nie tylko określonym typem kobiet, ale także specyficznym gatunkiem literackim utworów (pogranicze powieści sensacyjnej, kryminalnej, satyry, groteski, prozy humanistycznej).

Wydaje się, że stylizacja języka bohaterek powieści Chmielewskiej na polszczyznę potoczną przyniosła zamierzony efekt. Ma się wrażenie, że czytelnik obcuje z prawdziwymi postaciami, które operują językiem znanym z rzeczywistości, które dobrze ten język znają i potrafią się nim posługiwać w określonych sytuacjach.

\section{Ewa Kaptur}

\section{Stylization of the Language of Women Protagonists in the Novels by Joanna Chmielewska into Colloquial Polish}

The aim of the article is to analyse the language of women protagonists of the selected prose writings by Joanna Chmielewska stylized into colloquial Polish. Several conclusions stem from reading her novels.

First, stylization of the language of women protagonists into colloquial Polish appears in the narrative layer and in dialogues.

Second, Joanna Chmielewska in her novels faithfully mirrors the colloquial variety of Polish, additionally enriching it with linguistic innovations of various type. Emotional tone prevails in the utterances of women, being especially manifest in the use of numerous exclamations, onomatopoeic words, calls or the words generally considered as vulgar or offensive. This also refers to diminutive expressions and the affectionate terms used in the function of words as well as pejorative expressions.

The women protagonists of the novels speak the language rich in idioms and proverbs. They appear in an unchanged form but even more often are subjected to diverse linguistic experiments. The reader's attention is attracted to numerous contaminations and supplementary innovations.

It should be noted that colloquialism in Chmielewska's writing is primarily manifested at the linguistic level; to a much lesser degree in the selection of topics. In the studied texts there are no typical everyday themes connected with a stereotypically understood role of a woman.

\footnotetext{
15 Por. K. Handke, Język a determinanty płci, s. 27.
} 
